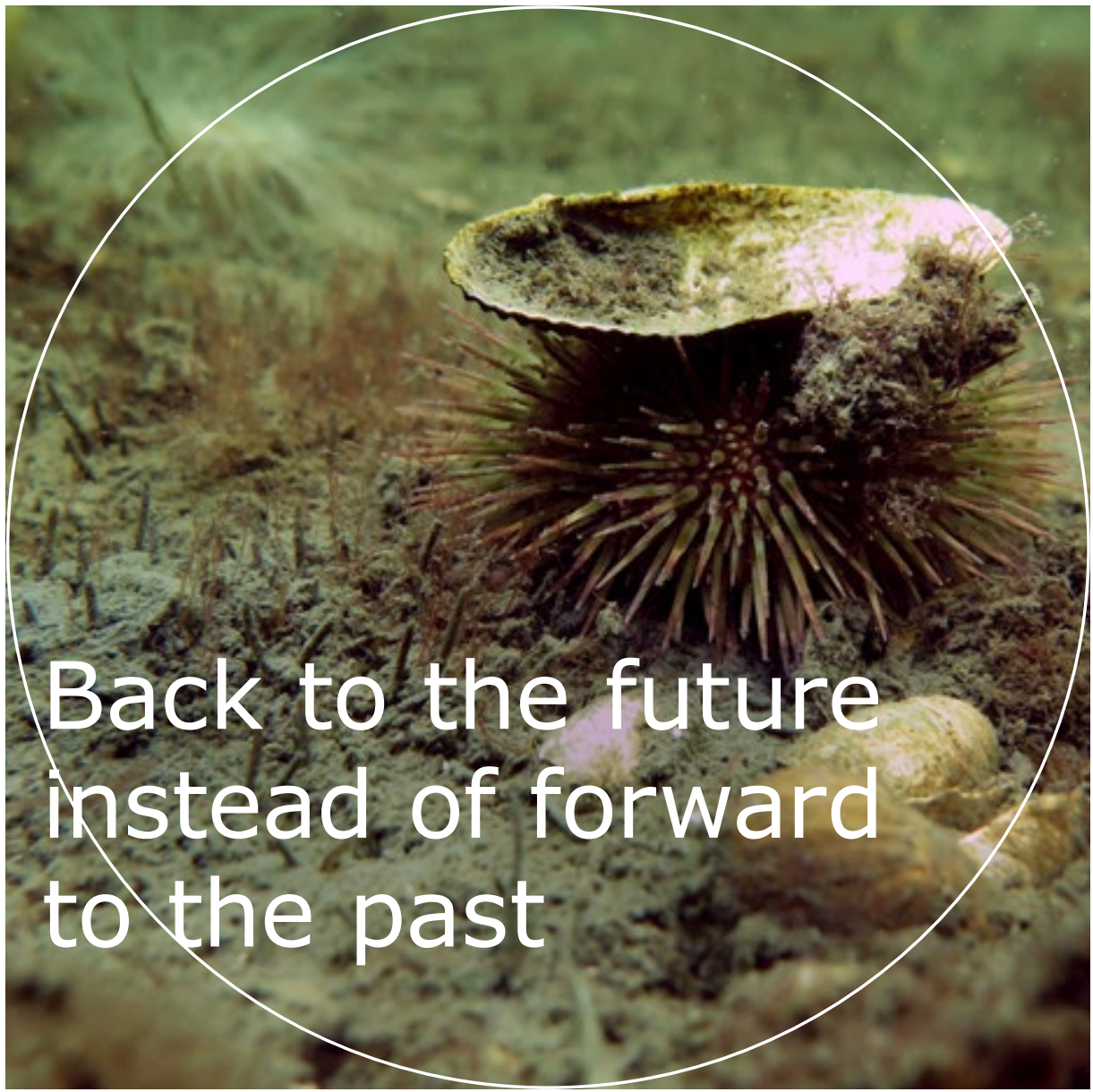

Prof.dr A.J. Murk

Inaugural lecture upon taking up the position of Professor of Marine Animal Ecology at Wageningen University \& Research on 2 November 2017 



\section{Back to the future instead of forward to the past}

Prof.dr A.J. Murk

Inaugural lecture upon taking up the position of Professor of Marine Animal Ecology at Wageningen University \& Research on 2 November 2017 
DOI HTTPS://DOI.ORG/10.18174/461060 ISBN 978-94-6343-364-8 


\section{Back to the future instead of forward to the past}

\section{Introduction}

Esteemed Rector Magnificus, dear colleagues, students, family and friends, The growth of the world population has required, and still requires, intensification of the food production. The ancient hunter/gatherer style of living of our forefathers could never have supported the increasing demand for food. The cultivation of the soil for the growing of crops intensified further, and currently a manifold of food production per hectare is achieved compared to what would have been possible by only gathering. This intensification was possible because of technological innovations, increased fossil fuel use, breeding programmes and fertilizer application. The carrying capacity of the terrestrial environment for the human population is much higher now but it has also led to problems of land erosion, water shortage etc. Fortunately, current developments focus on making agriculture more sustainable, closing nutrient cycles thus reducing eutrophication of the environment, reducing the water consumption and facilitating the natural enemies of pests species in an continuous effort to reduce the use of pesticides.

Still, the demand for food is growing, and as opportunities on land are approaching their limits, it is suggested to better utilize the potential to produce food from the oceans. Also for other developments and activities, people aim to make greater use of the seas. The European commission has even developed an official long term strategy to support sustainable growth in the marine and maritime sectors, called Blue Growth. Seas and oceans are promoted as drivers for the European economy that have a great potential for innovation and growth. The current 'blue' economy roughly represents 5.4 million jobs and generates a gross added value of almost 500 billion Euros a year.

Further growth is going to be stimulated in 5 areas: -aquaculture; -coastal tourism; -marine biotechnology; -ocean energy and -seabed mining (figure 1). 
Of course it is great to make use of a 'sea of opportunities'. The seas, however, already are quite intensively used.

The OSPAR commission, an international commission that reports on the quality of the marine environment of the NorthEast Atlantic, prepared maps that describe the spatial distribution and intensity of important uses such as fisheries and aquaculture, shipping, ports, oil and gas industry, and offshore wind energy. Below you can see the shipping intensity (figure 2a) and off-shore oil and gas installations (figure $2 b)$ in the North Sea.

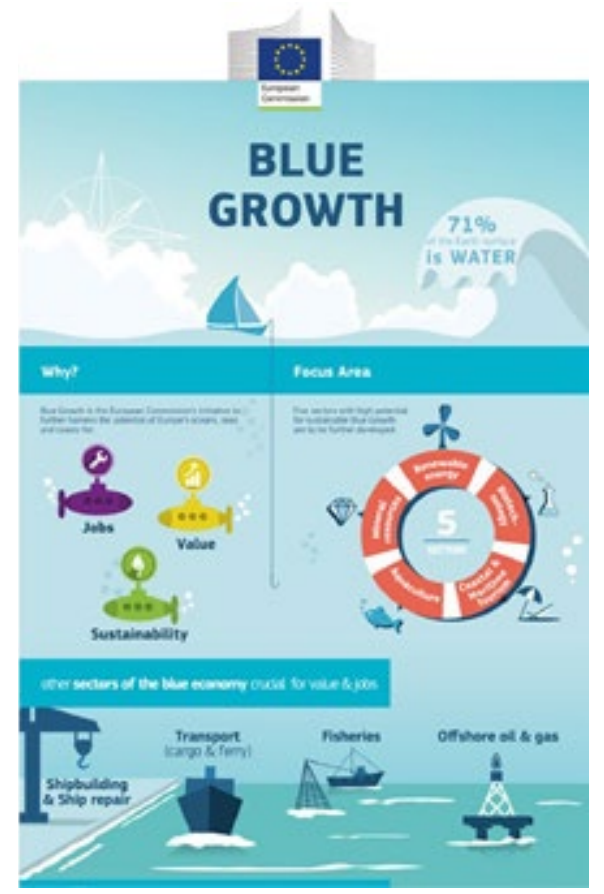

Figure 1: Blue growth strategy of the European commission (ec.europa.eu/maritimeaffairs/policy/ blue_growth_en)
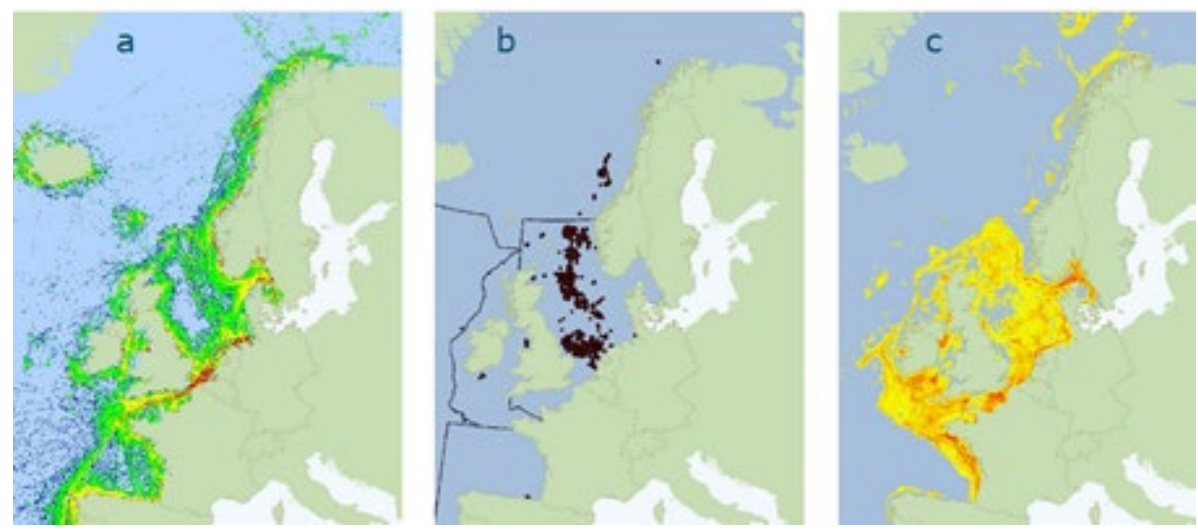

Figure 2: a) Intensity of shipping during 1 week in February (red: $>10$ 000), b) Oil and gas installations,

c) Intensity of shipping for demersal fishing during 1 week in February (red: swept area ratio 57,9-119.7).

Data source: OSPAR maps North Sea (oap.ospar.org/en/ospar-assessments/intermediate-assessment-2017/socio-economics/) 
Figure 2c shows current shipping intensity of demersal fisheries with seabed abrasion. The 'swept area ratio' is the ratio of the area swept by the fishing gear to the surface area of a cell. When the ratio is 1 it means that when trawling tracks are not overlapping, every spot in the cell is swept once. The highest intensity category is $57.9-119.7$ in only a 1 week period in February 2017. Bottom trawling with current powerful ships actually resembles the intensive harvesting as occurs in agricultural fields. In intensively fished areas the seabed is ploughed up to 10 times per year, which especially wipes out long-lived species including the ecologically important bioturbators ${ }^{1}$. According to a recent study, bottom trawling occurs in $98 \%$ of the $0-200$ $m$ deep North Sea bed, with an intensity between 1-10 times per year².

Even more historical hunting and gathering food from marine resources already had quite an impact as well, and this has increasingly changed the marine environment, especially the seafloor. For example, 2 centuries ago intensive trawling activities were already taking place with sailboats (figure 3 ). Oysters were a cheap and seemingly inexhaustible source of valuable animal proteins for the common people.

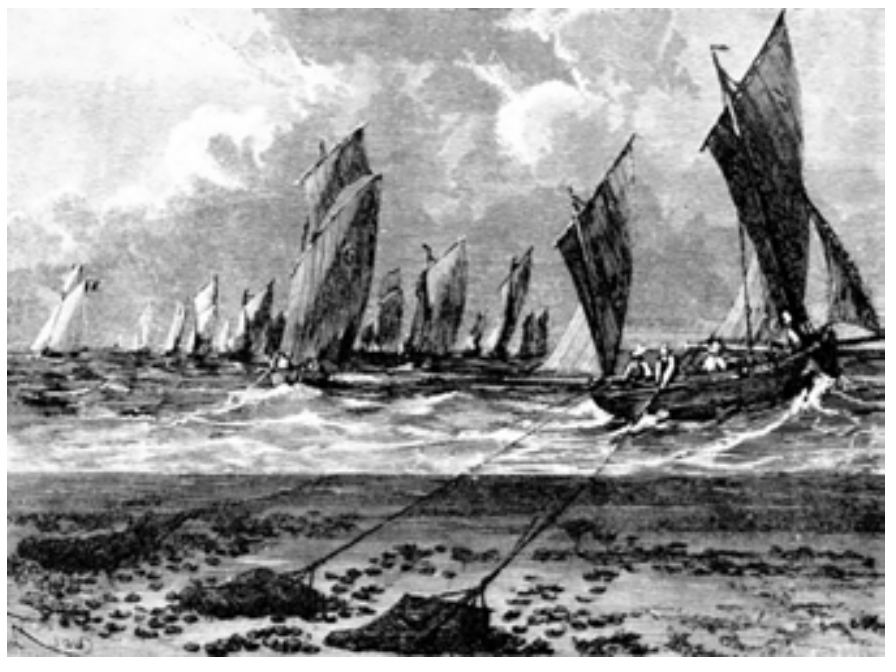

Figure 3: Oyster fishing around $1875^{3}$.

1 Rijnsdorp et al., 2018. Estimating sensitivity of seabed habitats to disturbance by bottom trawling based on the longevity of benthic fauna. Ecological Applications, 28(5), pp. 1302-1312

2 Eigaard et al., 2017. The footprint of bottom trawling in European waters: distribution, intensity, and seabed integrity, ICES Journal of Marine Science, 74(3), 847-865. doi:10.1093/icesjms/fsw194

3 https://commons.wikimedia.org/wiki/Category:Fishing_dredges_in_art 
At the end of the 19th century, decades after the fishing began, still extensive oyster-banks could be found in the North Sea according to the fishermen (figure 4$)^{4}$. They also reported extensive areas with stones, rubble, and moorlag (remains of trees). As the fishing boats became geared with more powerful engines the harvesting became more efficient and complete. This led to the complete removal of oyster- banks in the North Sea.

The former great diversity of hard substrates and shell-fish beds present in the North Sea provided important habitat for numerous marine benthic species and the necessary shelter and food source for juvenile fish such as cod and rays. Unfortunately, our current North Sea bottom mostly consists of ploughed sand habitat as only $0.3 \%{ }^{5}$ of the seabed is fully protected against any form of seabed disrupting fisheries.

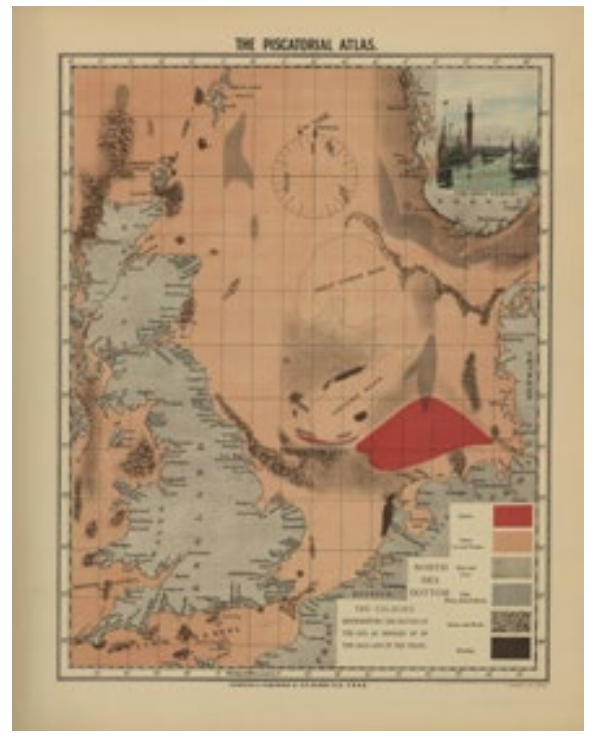

Figure 4 The piscatorial atlas of the North Sea, English and St. George's Channels, illustrating the fishing ports, boats, gear, species of fish (how, where, and when caught), and other information concerning fish and fisheries (Olsen, O.T., 1883). ${ }^{4}$

The first moment that I realised how intensively used the North Sea is, was during a presentation from my colleague Han Lindeboom at the North Sea days in 2008. He is founder and passionate advocate of a more nature inclusive marine spatial planning in the North Sea and just had published an Ecological atlas of the North Sea for area

4 Olsen, 1883 (www.vliz.be/wetenschatten/beeldbank.php?album=2397)

5 Vrooman et al., 2018. Gebiedsbescherming op de Nederlandse Noordzee. De stand van zaken in relatie tot visserij. Stichting De Noordzee, Utrecht (in Dutch) 
protection purposes ${ }^{6}$. Han showed in overlaying maps the many uses people make of the North Seas, and how little space is left for nature. He suggested to fully protect $15 \%$ of the North Sea, reserve $5 \%$ for innovative, less destructive, fishing methods and $5 \%$ for offshore wind energy parks without fishing. This is also referred to as 'the $25 \%$ of Han'. In this proposal $75 \%$ of the North Sea can be used for fishing.

Of course bottom trawling also occurs in our neighbouring countries. Figure 5 shows the landings of bottom-living fish per unit of fishing power of large British trawlers Since 1889. The developments are not very different from those in the Netherlands. The authors explain that in the graph 4 phases can be recognized: Phase 1, from 1889 to the onset of World War I, corresponds to the rapid industrialization and intensification of fishing in home waters. The fleet was converted from sail to steam power. Landings increased, but new technology, more boats and expanded grounds masked a steep decline in fish stocks. Phase 2 covers the inter-war years of 1919-1939 with a second wave of expansion as fishing vessels sought new grounds in the Arctic and West Africa. The exploitation of these unexploited grounds brought an increase in landings per unit of fishing power that lasted until the late 1950s. Phase 3 covers the abrupt collapse in catches between 1956 and 1982 as distant-water stocks became fully exploited. Towards the end of this period, there were strong declines in fish stocks and fish landings collapsed. Phase 4 began in 1983 with the formal creation of the Common Fisheries Policy.

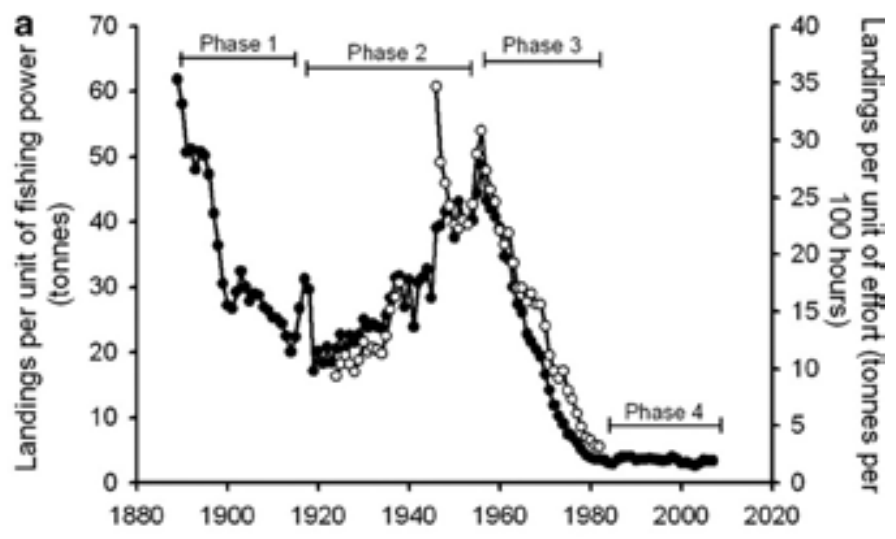

Figure 5: Landings of bottom-living fish per unit of fishing power of large British trawlers. Source: The effects of 118 years of industrial fishing on UK bottom trawl fisheries ${ }^{7}$

6 Lindeboom et al., 2008. Ecologische Atlas Noordzee ten behoeve van gebiedsbescherming, Wageningen IMARES.

7 www.nature.com/articles/ncomms1013/figures/2v 
Figure 6 shows the development of the plaice population in the North Sea. Since 2000 the government is monitoring the fishing vessels with a Vessel Monitoring System via satellite. After quite some international criticism on the Dutch government, several measures were taken including stricter enforcement and a reduction in the number of fishing vessels. This has resulted in a sharp increase in plaice numbers and the current plaice population density is safely above the sustainability limit. The year 2016 was a top year for Dutch cutter fishing. The salaries for the fishermen increased with $41 \%$ in one year to 106 million euro, and also the net gain more than doubled.

\section{Scholstand in Noordzee}

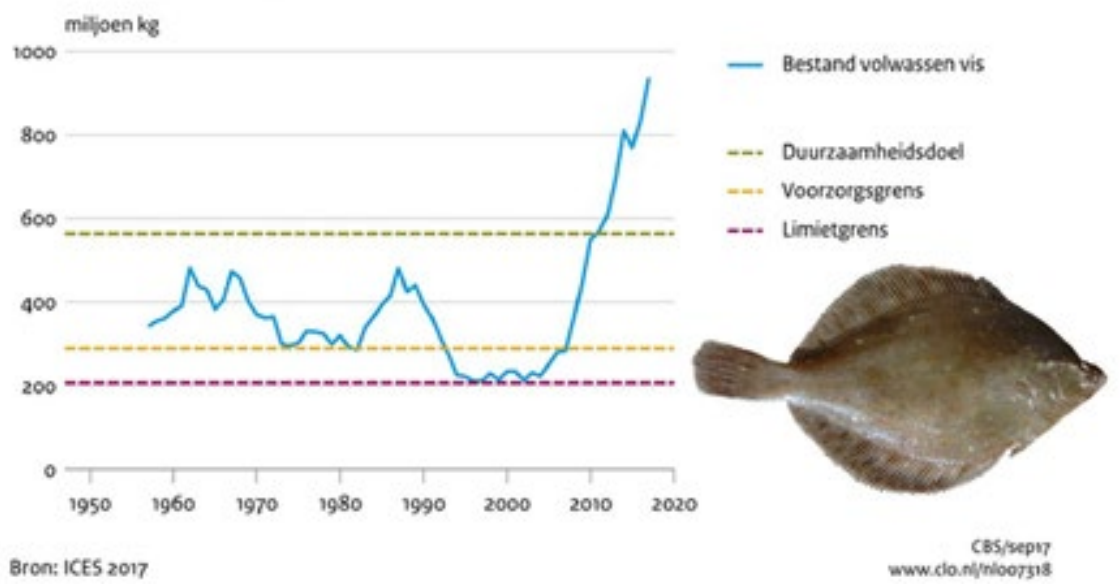

Figure 6: Development of European plaice (Pleuronectes platessa) populations in the North Sea .

Flatfish typically appreciate more disturbed sandy bottoms in which they can make themselves virtually invisible and where they find opportunistic short living prey. The sandy bottom functions like a flatfish farmland where, like in grain fields, other ecological functions are limited. Also the herring populations are now back in the safe zone (CBS 2017'), following good fisheries management and perhaps supported by the collapse of cod numbers compared to 1986. Due to overfishing and probably also habitat loss and possibly climate change, the cod stocks collapsed (CBS 2017 $)$. As cod is one of the top predators of sprat and herring in the marine ecosystem, those will profit from the lack of predation. Cod landings from different fishing grounds

8 ICES 2017, as reported by CBS 2017 (www.clo.nl/indicatoren/nl0073-visbestanden-in-de-noordzee, in Dutch) 
lost over $95 \%$. Fortunately the numbers of smaller cod are now slowly recovering, in the northern population more than the southern, which could be related to the climate change as well.

In Newfoundland they unfortunately were too late with a good stock assessment and fisheries management. Cod fishing in Newfoundland had been carried out at a subsistence level for centuries. Waters were considered to be exceptionally plentiful, however, after intense overfishing the population and thus the fisheries collapsed in the 1990s. Due to greed, lack of foresight and poor local administration the moratorium on cod fishing came too late. By 2002, after a 10-year moratorium on fishing, the cod had still not returned. The local ecosystem seemed to have changed, and also the forage fish for cod, such as capelin, were overfished as bycatch ${ }^{9}$. The waters appeared to be dominated by crab and shrimp rather than fish. In Newfoundland alone, over 22,000 fishers and plant workers from over 400 coastal communities became unemployed. Interestingly, after some time a thriving invertebrates fishing industry emerged. As the predatory benthic cod population declined, snow crab and northern shrimp proliferated. This became the basis for a new industry that is roughly equivalent in economic value to the cod fishery it replaced. ${ }^{10}$

I really hope we will manage to prevent this from happening to the eel population and fisheries. European eel (Anguilla anguilla) has been immensely popular and important for both human and wildlife. Actually it was still an abundant species more than 100 years ago. Unfortunately, currently eels face worldwide population collapses. Figure 7 shows how the European eel glass influx is declining. The 2017 level of European eel recruitment compared to the 1960-1979 average is $1.6 \%$ for the North Sea and 8.7\% for Elsewhere Europe (ICES, 2018 ${ }^{11}$ ). Also the Japanese and the American eel populations are strongly declining. ${ }^{11}$

European eel has a very special life cycle including 2 long migrations of around 6000 $\mathrm{km}$ from and to the Sargasso Sea. In Europe they arrive as tiny glass eels, that find their way into the estuaries and rivers by smelling compounds such as geosmin, produced by symbiontic bacteria of sea grass. In areas with eelgrass and other water plants they find food and hide from predators. The eel then migrate further upstream

9 Summary of events leading to the collapse of the Newfoundland cod fishery: www.revolvy.com/pagel Collapse-of-the-Atlantic-northwest-cod-fishery

10 Hamilton and Butler, 2001. Outport Adaptations: Social Indicators through Newfoundland's Cod Crisis Human Ecology Review, Vol. 8, No. 2.

11 Dekker, 2003. Status of the European eel stock and fisheries. Pp. 237 -254. In Aida, K., Tsukamoto, K. E Yamauchi, K. (Ed.), Eel Biology, Springer-Verlag, Japan, Tokyo, ISBN 4431004580, 497 p. 
of rivers and find places to develop further and grow big. After several years they need to migrate back to the estuaries, hang around for a few weeks for adaptation to marine conditions, and then disappear for a mysterious $6000 \mathrm{~km}$ one way migration back to the Sargasso sea where they spawn and die.

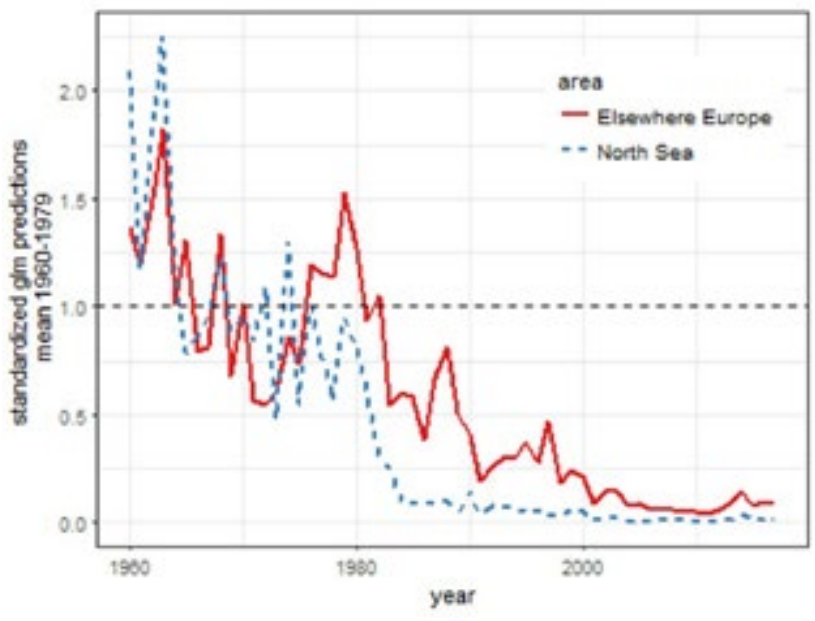

Figure 7: Eel recruitment index: geometric mean of estimated (GLM) glass eel recruitment for the continental North Sea and Elsewhere Europe series updated to 2017 (ICES, 2018 ${ }^{12}$ ). The GLM (glass eel area: year + site) was fitted on 43 time-series comprising scaled to the 1960-1979 average.

No single cause can explain the extreme eel population decline. It is due to an array of interacting reasons, including overfishing and poaching of adults and glass eel, introduction of diseases via import of animals for aquaculture from other parts of the world, toxic compounds, hydropower stations chop them to pieces, increasing numbers of natural predators, lost habitats, climate change related changing ocean currents and plankton composition, blockage of migration routes by dikes and dams, destruction of eel habitat, both in the river where they grow up as well as in the estuaries where they hide during smoltification, etc. At a certain moment a minimum density could be reached, where simply mates cannot find each other in high enough density for reproduction.

So much about the eel still is unknown, so many stakeholders are involved, who mostly blame others for the eel decline, or the conditions they cannot control. The problem is so wicked that we have chosen the eel problem as central casus in our

12 ICES 2018. Report of the Joint EIFAAC/ICES/GFCM Working Group on Eels (WGEEL), 3-10 October 2017, Kavala, Greece. ICES CM 2017/ACOM:15. 99 pp. 
interdisciplinary MSc course Environmental quality and governance. Students from very different backgrounds have to make an eel management plan to prevent eel extinction. The students struggle and learn a lot about how to deal with uncertainties and political games. A struggle that strikingly resembles the one in 'the real world'.

A big problem remains that the marine world is not easily accessible for many people, especially under water. When a forest is obliterated this usually is noticed and people may protest. However, when in a marine area the underwater habitat is wiped away hardly anyone will see or realise this. If given the opportunity, recovery may take decades to ages without active restauration effort.

Sports fishermen, divers, and also professional fishermen know where they can still find big cod. In and around the shipwrecks that are still present in the North Sea. Therefore the volunteers of the "Duik de Noordzee schoon"13 foundation are very busy every year removing tons of lost fishing gear from these wrecks to prevent continued ghost fishing.

Other marine problems, however, are quite visible and usually this stimulates action to solve it. For example, when I was young and still living with my parents in Katwijk aan Zee, we always had to clean the tar from our shoes with white spirit after a beach walk. Accidental oil spills happened regularly, and nobody seemed to mind dumping oil containing waste water in the sea. Among others, because nowadays ships need to be double walled which strongly reduces the risk of oil flowing out after a crash, I hardly ever find tar on the beach anymore. This, unfortunately, is not the case for all areas in the world. Tar balls, for example, were washed ashore on Bonaire's beaches after an oil spill in Venezuela in 2017.

Also very obvious during my youth were the episodes of great numbers of dead fish floating in the river Rhine. Not only following the enormous chemical spill due to the Sandoz fire, but also because the water became depleted of oxygen after algal blooms due to lack of waste water treatment, runoff of from heavily fertilized agricultural fields and phosphate-containing laundry detergents. These shocking episodes, fortunately, triggered important legislation and international negotiation, as rivers and seas do not stop at national borders. By now, international and European legislation such as the EU Water Framework Directive, the Marine Strategy Framework Directive, ICES, OSPAR, Natura 2000 have stimulated great effort to improve the ecological quality of aquatic and marine systems, with often impressive results. I rarely see 'sunbathing' fish anymore.

13 www.duikdenoordzeeschoon.nl/5763-2/ 
Unfortunately massive fish kills still do occur in other parts of the world. It is not difficult to find recent reports of massive fish $\mathrm{kills}^{14}$ such as the one last year in Vietnam's Ha Tinh province. Here the Taiwanese-owned Formosa Plastics Corporation is developing a giant steel complex. Since April 4, 2016, when the plant was suspected to have released a torrent of toxic chemicals into the sea, more than 70 tons of dead fish washed up on Vietnam's shores. And also in Florida massive fish kills occurred, caused by a combination of environmental factors. Warmer waters, increased precipitation and pollutant runoff made way for toxic algae blooms and brown tide, ultimately depleting the water of oxygen. After heavy rains, the water eventually made its way into estuaries via urbanized neighbourhoods, picking up fertilizer and other pollutants along the way.

Other things that are noticeable are climate changes. At increasing rates temperatures rise, big storms, long droughts and heavy rains occur, and $\mathrm{CO}_{2}$ levels go up. These effects are so huge and ubiquitous that we hardly know where to start solving them. Although we hope we can slow down the rate at which climate change happens, the process only seems to accelerate.

Some species enjoy rising temperatures more than others. In the Netherlands, for example, "Stichting Anemoon", an organisation of amateur marine biologists, yearly reports new species, often originating from southern Europe. While the cod does not like warmer water anchovy and hake love it. This is a natural process, they are simply better adapted to the new conditions. As long as the ecosystem functions well this basically is not a problem. Things can, however, run terribly out of hand when not enough species are present anymore to control population increases at a lower trophic level.

In several parts of the world 'jellification' of the oceans have been reported. Clearly several marine ecosystems and food webs are out of balance, and people fear it may be too late to stop the jellyfish from 'taking over the seas'. Not only does this give problems for fishermen that sometimes have nets full of jellyfish, but massive amounts of jellyfish can also clog cooling water intake and kill farmed salmon.

Interestingly, in a publication by $\mathrm{Uye}^{15}$ the jellyfish blooms are suggested to be the consequence of warmer sea water and increased food availability because of eutrophication. These factors, indeed, are favourable for jellyfish. An exploding

14 https://news.mongabay.com/2016/o5/taiwanese-chemical-spill-thought-cause-mass-fish-die-off-vietnam/; https://edition.cnn.com/2016/03/25/us/florida-fish-kill/ 
population size of a certain species, however, normally is an immediate opportunity for other species to have a great meal. As you can see in figure 8, the fish catches first go up dramatically, then collapse, and only 6 years later does the first jellyfish bloom occur.

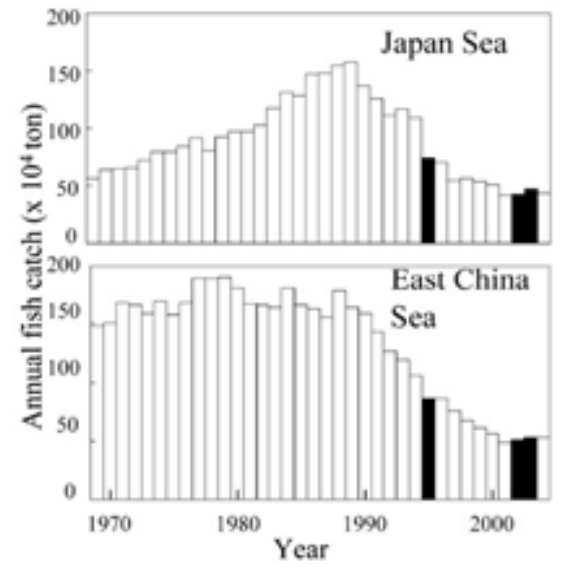

Figure 8: Annual fish catch in the East China Sea and the Japan Sea by Japanese fishing vessels. Blooms of the giant jellyfish (Nemopilema nomurai) medusa are shown by dark columns ${ }^{15}$.

Many animal species love to eat tonnes of, even really big, jellyfish. Unless, of course, these predators are decimated though overfishing (such as tuna) or (such as for leatherback turtles) because of the destruction of their seagrass beds and nesting opportunities, egg exploitation and also because of bycatch.

The sad thing is that if jellyfish become dominant they will catch significant amounts of fish larvae, small fish and their food (zooplankton) resulting in a downward cascade towards a potential ecosystem phase shift. Of course the jellyfish are not to blame. System shifts resulting in loss of precious species have happened before, and it may currently be happening to the great sharks because of massive fishing for their fins and meat and accidental bycatch. Sharks and rays survived several mass extinction episodes, but quite some of these species now are brought close to extinction. Figure 9 shows the strong decrease in numbers of great sharks, so-called apex predators. As a consequence the populations of mesopredators such as smaller sharks and rays (figure 9) but also lionfish numbers are not controlled anymore with cascading effects to lower trophic levels ${ }^{16}$. These mesopredators then can decimate their prey such as scallops in the example of figure 9.

15 Uye, 2008. Blooms of the giant jellyfish Nemopilema nomurai: a threat to the fisheries sustainability of the East Asian Marginal Seas. Plankton \& Benthos Research, 3, pp125-131

16 Myers et al, 2007. Cascading Effects of the Loss of Apex Predatory Sharks from a Coastal Ocean. Science 315, 1846. DOI: 10.1126/science.1138657 

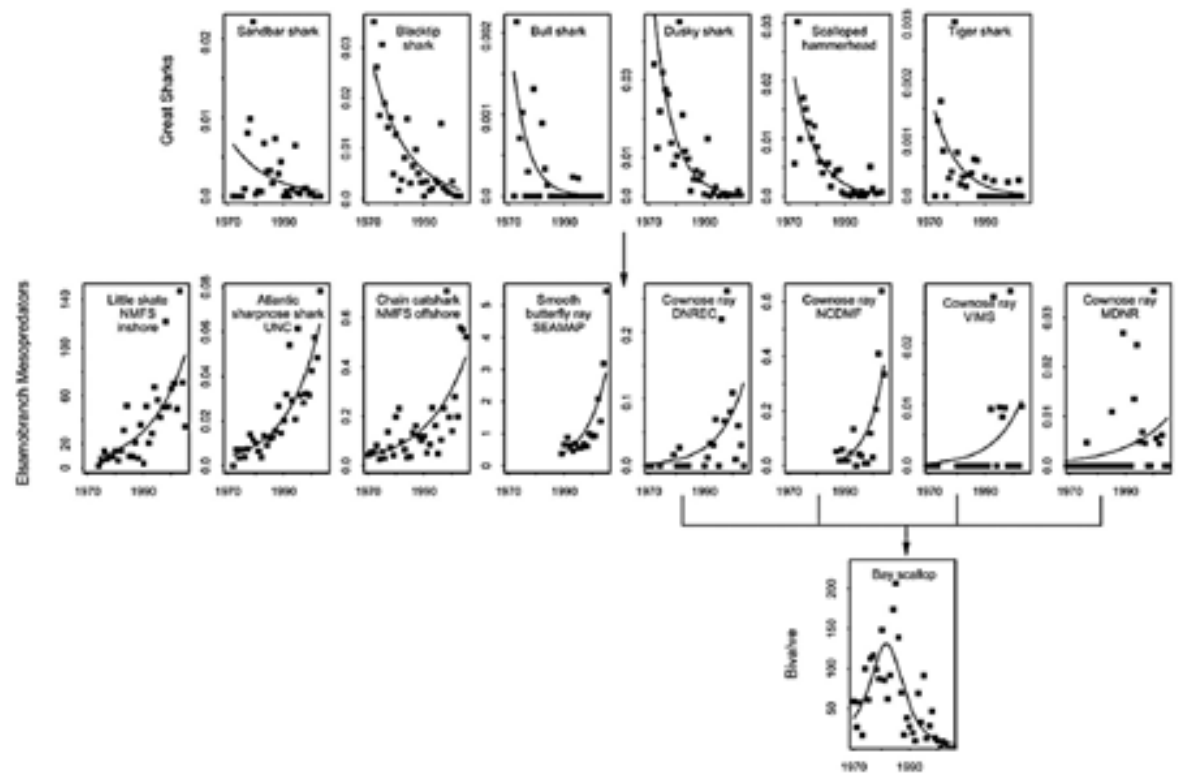

Figure 9: Change over time of apex elasmobranch predators (top), elasmobranch mesopredators (middle) and bivalves (bottom) (source Myers et al. 2007)16.

Of course we can quickly collect DNA and freeze fertilised eggs to be able to bring them back in a period with less threatening human activities. This will be then much easier than what e.g. the 'Revive and restore' foundation is trying to do, bringing back the once so abundant passenger pigeon (Ectopistes migratorius, trekduif) in so-called de-extinction projects ${ }^{17}$. It would be a tragic failure of mankind, now that we know more about mechanisms of extinction and conservation, if we would let this happen to e.g. the short fin Mako or other sharks.

In the Dutch North sea we also witnessed a strong decline in rays and sharks. Some seem to be slightly coming back, but for example for the shark species spurdog (Squalus acanthias), or the 'common' skate (Dipturus batis) the situation is really grave. The problem with many larger sharks and rays is that they take many years to mature, with as extreme example the Greenland shark that only reaches puberty at the age of 150 years and they can become 400 years old. The large elasmo-branches only produce limited amounts of eggs and sometimes juveniles when they are live bearing, for example 40 or only 10 . And before they reach sexual maturity they are so much bigger that they often end up as bycatch before they can even reproduce.

17 reviverestore.org/about-the-passenger-pigeon/ 
Last year fishermen from Den Helder caught a large skate near the English coast. Of course it is a pity the animal is dead now, but hopefully they will return to the Dutch North Sea once survival conditions are better for them again. These animals need areas without fishing and shellfish reefs as nurseries and food sources for juveniles.

It is important to realise that the anthropogenic impacts occur against the back-ground of natural changes that we cannot control, namely the large scale of climatological changes that have been occurring already since millions of years. At the last glacial maximum, 18.000 years ago, the ocean level was $100 \mathrm{~m}$ lower. All current coral reefs were land at that time.

About 9000 years ago, at the end of the last ice age, the North Sea was land (called Doggerland, figure 10) with the Shetland hills and the Dogger hills ${ }^{18}$. Warmer climate exposed a vast continental shelf for humans to inhabit. Further warming and rising seas gradually flooded low-lying lands. About 8,200 years ago a catastrophic release of water from a North American glacial lake and a tsunami from a submarine landslide off Norway inundated the remaining Doggerland. The former Shetland and Dogger hills are now the Shetland islands and the Dogger bank.

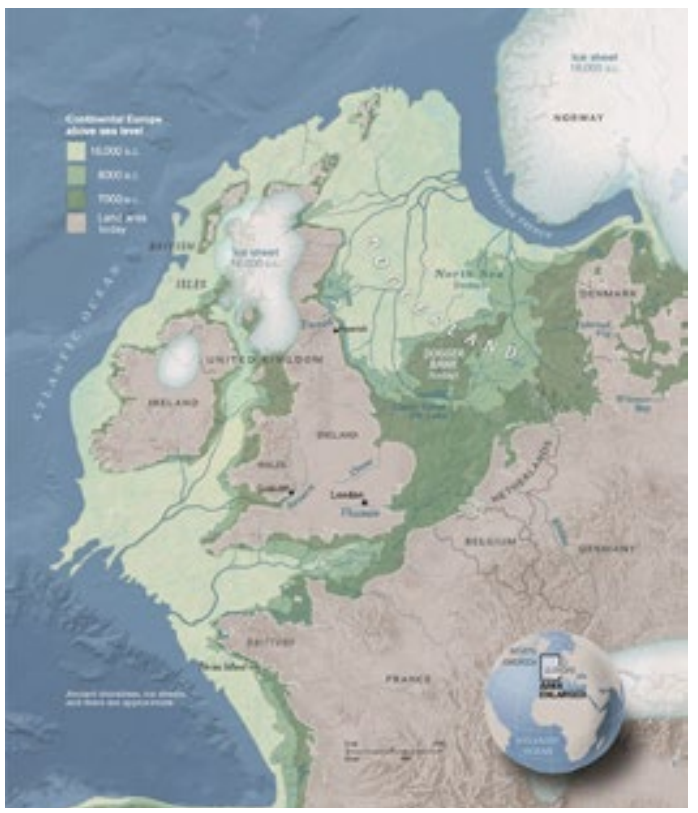

Figure 10: Doggerland, inhabited by hunter-gatherers until about 6000 years ago ${ }^{18}$.

18 www.nationalgeographic.org/maps/doggerland/ 
Ecosystems continuously have to adapt, communities change and during some episodes life just was not possible. Around 252-247 million years ago, the tropics zone was so hot that it was a 'dead zone' (figure 11). Marine reptiles (ichthyosaurs), terrestrial tetrapods and fish almost exclusively were found at the cooler higher latitudes with rare exceptions.

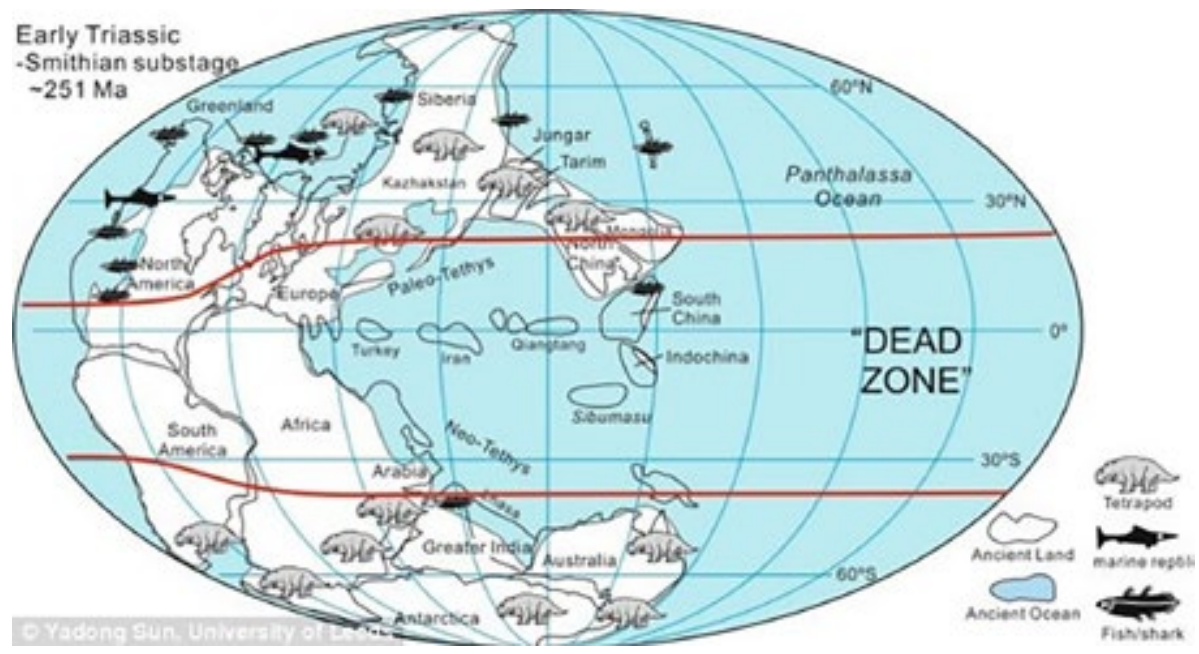

Figure 11: During the greatest mass extinction in Earth's history the world's oceans reached $40^{\circ} \mathrm{C}$ which was lethally hot for most animals and plants. ${ }^{19}$

Interestingly, the tropics currently harbour the greatest species diversity on earth. It just takes a few million years, but every time a mass extinction seems to have resulted in many new species appearing. Note that this still means many million years later, so time scales that do not provide any relief for humanity today.

To adapt or not to adapt, that is the question. Not only ecosystems, but also human societies must adapt including how they make use of marine ecosystem services. And given the various limits we have reached in many ways there is absolutely no time to lose. We can learn from successes and failures in our terrestrial world, and thus work towards science based innovation and eco-inspired design. Improving the way in which we interact with our marine environment may be more complicated given the vast areas, the depths, the openness of the systems, the unclear proprietary rights, the lack of sense of community and social control, and many other factors.

19 Sun et al, 2012. Lethally Hot Temperatures During the Early Triassic Greenhouse. Science, 338 (6105): 366-370 
But in general we know the

\section{recipe for a healthy, productive and resilient marine ecosystem:}

1 Ensure the necessary diversity of sufficient high quality habitats for all life stages of the known key players

2 Enable connectivity between habitats required to fulfil life cycles and to overcome the risk of isolated populations. This includes brackish deltas and fresh water environments.

3 Support full food web functionality. All keystone functions like grazing, adequate reef builders, and large top predators controlling mesopredators should be present and in balance. Harvesting of species should not exceed population growth compensation.

4 Ensure good environmental quality. This means no excessive nutrient or particulate matter loads, toxic compounds far below effect levels and clear water to enable plant life also at greater depths.

Nature will then follow opportunities. If you don't want certain consequences, e.g. jellyfish blooms, then don't create the opportunities for them within the ecological contexts and the local environmental conditions.

Once we understand what species need in order to thrive, it is possible to estimate what the consequences will be of certain scenarios of climate change. This will allow us to manage the populations of species and kick-start deteriorated ecosystems so that they will become more productive and resilient and can adapt to changes that inevitably will continue to occur. That is the field to which the marine animal ecology (MAE) group wants to contribute with research, education and outreach (figure 12).

MAE was established in the summer of 2015. We study how marine animals adapt in response to a changing environment and the consequences for the ecosystem, its use and its management.
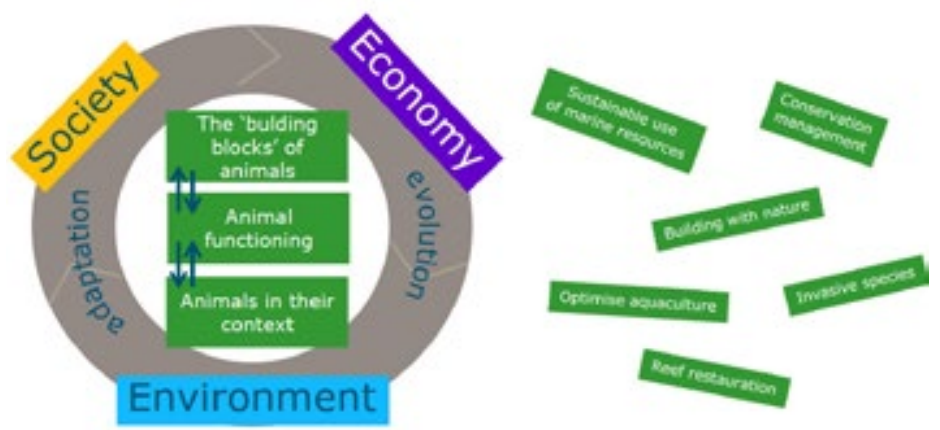

Figure 12: Work field of the marine animal ecology (MAE) group of Wageningen University. 
Our research includes different organismal levels, from eco-physiology, early life-stage development, population genomics, up to whole ecological community responses. We subsequently apply our research to gain an understanding of the consequences of anthropogenic activities to ecosystem services and conservation management. This understanding can then be applied to support management of healthy and biodiverse marine environments, increasing their resilience and opportunities for sustainable use.

Although most of my examples in the introduction were from the North Sea for reasons of consistency, MAE is very active in several other areas of the world as well. I will now give some examples of the work of the MAE group and also indicate some future activities with the following 6 MAE research themes:

1 Unveil how geographic patterns of marine communities have developed

2 Understand how, and to what extent, marine animals can adapt to stressors

3 Effects of marine pollution, ecotoxicology

4 Eco-inspired design of new/restored marine habitats

5 Scientific basis for marine conservation management

6 Scientific support for sustainable use of marine resources

\section{Unveil how geographic patterns of marine communities have developed}

As I mentioned before, the fact that it continuously changes is the only thing we know for sure about the environment. Many millions of years ago these changes have been extreme, but also in the last 10.000 years radical changes have occurred.

One of these consequences has been the formation of marine lakes in Papua New Guinea about 9000-7000 years ago. Lisa Becking, assistant professor at MAE, cleverly uses the marine lakes as a natural laboratory to study how the isolated marine communities have formed in this period under different local conditions. Of course coincidences also played a role in the composition of animals enclosed in the lakes. The chosen lakes vary in water temperature, salinity, $\mathrm{pH}$ and underground connectivity with the surrounding sea, and some represent predicted future ocean conditions.

Lisa and the PhDs Diede Maas and Christiaan de Leeuw (figure 13) study to what extent mussels and marine sponges have been able to adapt to the new conditions. This requires tough field work in those remote areas. In the lakes they register communities and collect samples for future molecular, histological and CT-scan analysis in Wageningen. If possible incubation experiments will be performed to study to what extent the observed genetic differences indeed represent a better adaptation of the mussels to the specific conditions in their lakes compared to other mussels. 


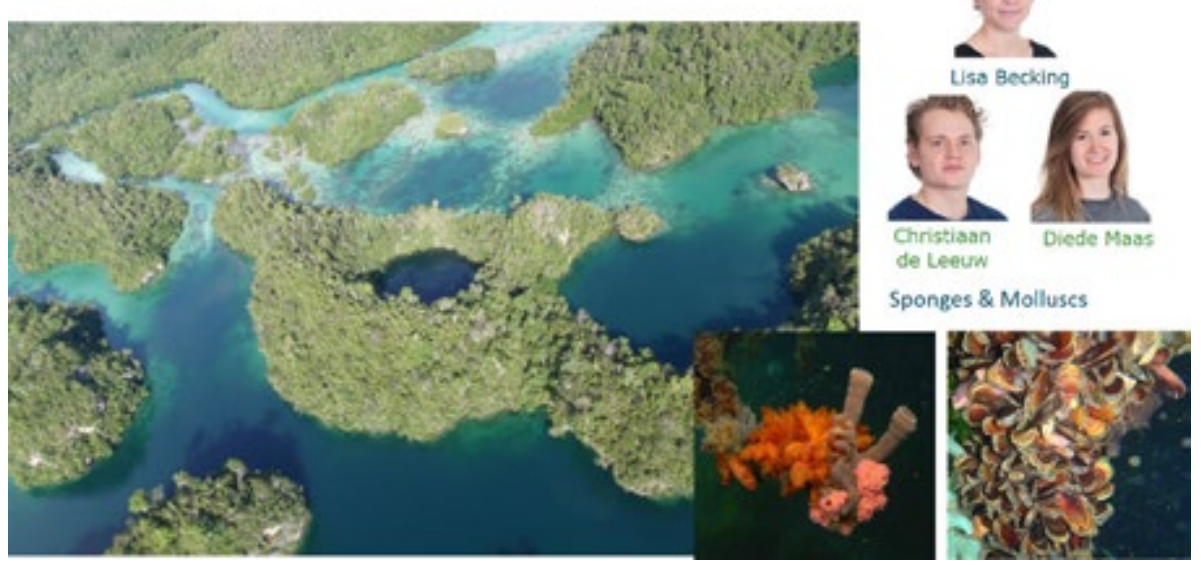

Figure 13: Unveil how geographic patterns of marine communities have developed in marine lakes in Papua New Guinea.

In some of these isolated marine lakes unique and beautiful animals have developed, including non-stinging jellyfish that may become victim of the increasing popularity by tourists to snorkel with them. By understanding their life history characteristics and vulnerability better, MAE hopes to contribute to conservation of these beautiful animals.

\section{Understand how, and to what extent, marine animals can adapt to stressors}

In the animal facilities in Carus, MAE uses a tropical room and a cold room for physiological and functional research. In the tropical room sponges and corals are being cultured in order to be able to study their physiological responses to single or combined environmental stressors under supervision of Dr Ronald Osinga, assistant professor at MAE, and Dr Tim Wijgerde (figure 14). For example the combined effects of higher temperatures, UV light intensity, sunscreen and/or suspended particles on coral health are studied, as in many parts of the world multiple stressors threaten coral reefs and their communities. Studying eco-physiological functioning of marine organisms in relation to the molecular mechanisms underlying traits under selection, may yield better insight in what makes organisms resilient or vulnerable.

We do not only perform experiments in the laboratory, but also incubate and expose marine benthic species in the field. For example PhD student Mischa Streekstra (figure 15) wants to understand why deteriorated reefs in the Caribbean often shift to elaborate sponge reefs while this is not happening in the Indo-pacific. One of the possible explanations lies in the iron that enters the reefs via air, runoff and rivers. A lot of iron-rich Sahara dust reaches the Caribbean areas but not the Pacific Ocean. 


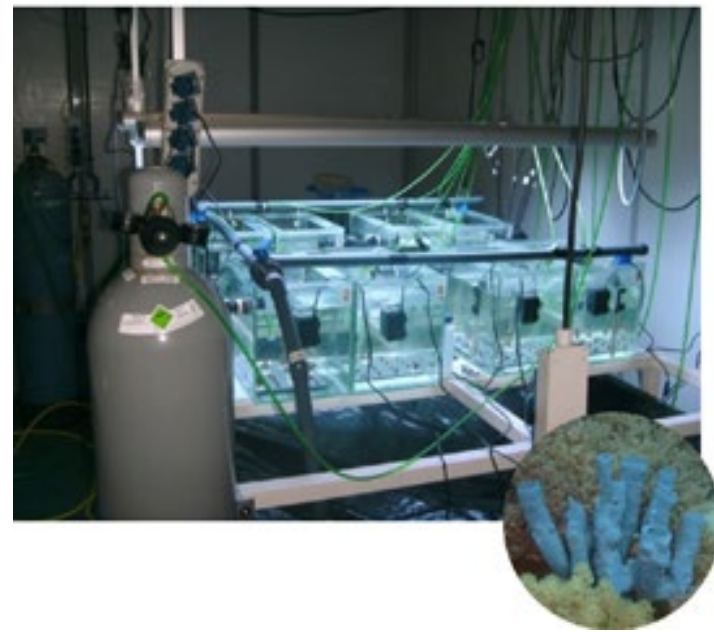

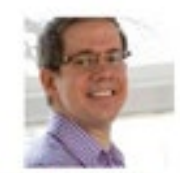

Tim Wijgerde

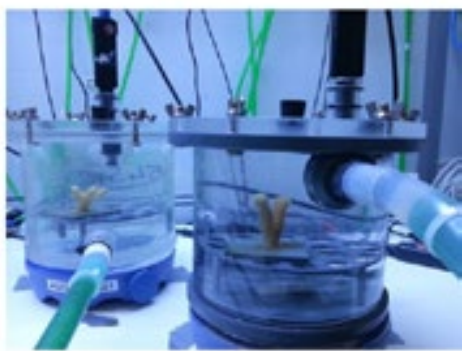

Figure 14: Ecophysiological experiments in Carus to study how and to what extent marine animals can adapt to stressors.

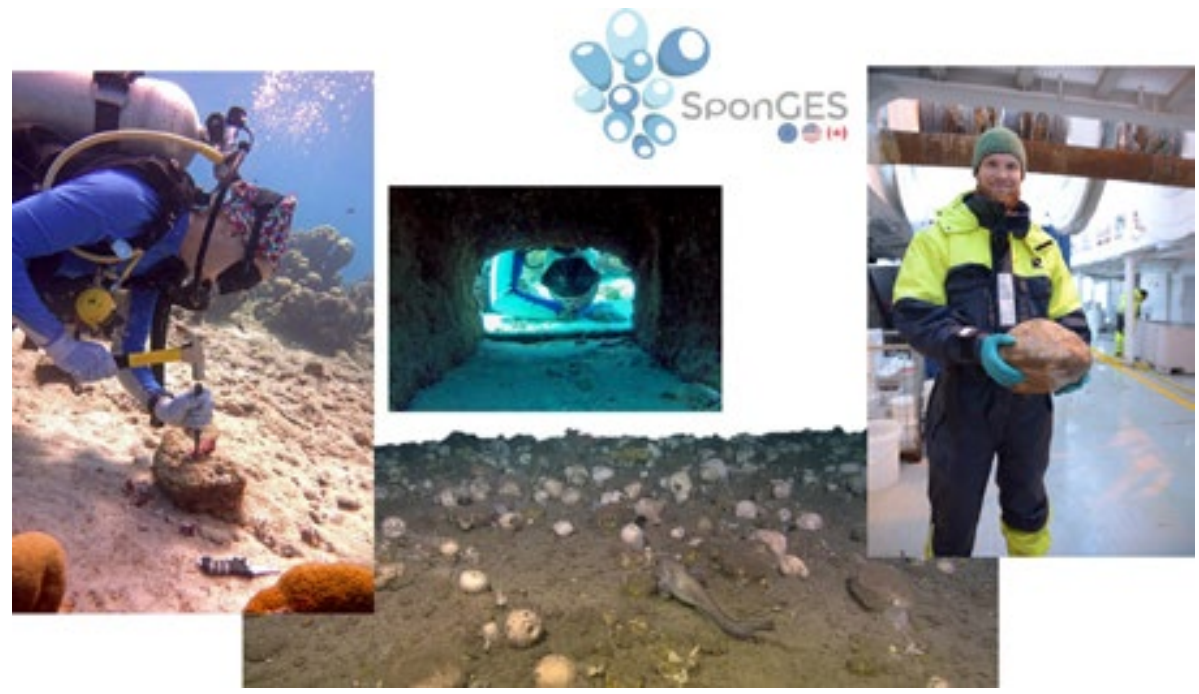

Figure 15: Eco-physiological field work in addition to laboratory incubations with sponges performed by PhD students Mischa Streekstra (left) and Erik Wurz (right).

Mischa performs in situ experiments in Moorea, French Polynesia, and at Curacao, where she is currently doing field work. 
PhD student Erik Wurz (figure 15) performs in situ and laboratory experiments with deep sea, cold water sponges. These sponges provide very important ecological services in the deep water benthic ecosystems. Not only do they provide habitat for many other species, but they also have a remarkable pumping capacity, cleaning the ocean waters from a massive amount of bacteria and other suspended materials. Unfortunately deep sea trawling and mining increase, not only destroying the sponge fields and removing substrates that the sponges need to grow on but also smothering vast sponge areas with mud.

Erik joined an expedition with other members of the European project 'Sponges' project on a high tech Norwegian research vessel. With remotely operated robot arms they collected sponges, and also incubated sponges in situ to determine their pumping rate. After a challenging period, Erik now is able to culture these deep sea sponges in Wageningen, keeping them healthy with very special filters set up with the help of Tim Wijgerde, and testing their physiological functioning.

\section{Effects of marine pollution, ecotoxicology}

Marine pollution and toxic compounds can originate from natural sources, industrial processes, oil drilling, and e.g. unsustainable shipping. We want to monitor the impact of exposures in the field, study mechanisms in the lab and perform multispecies experiments in small or large scale model ecosystems.

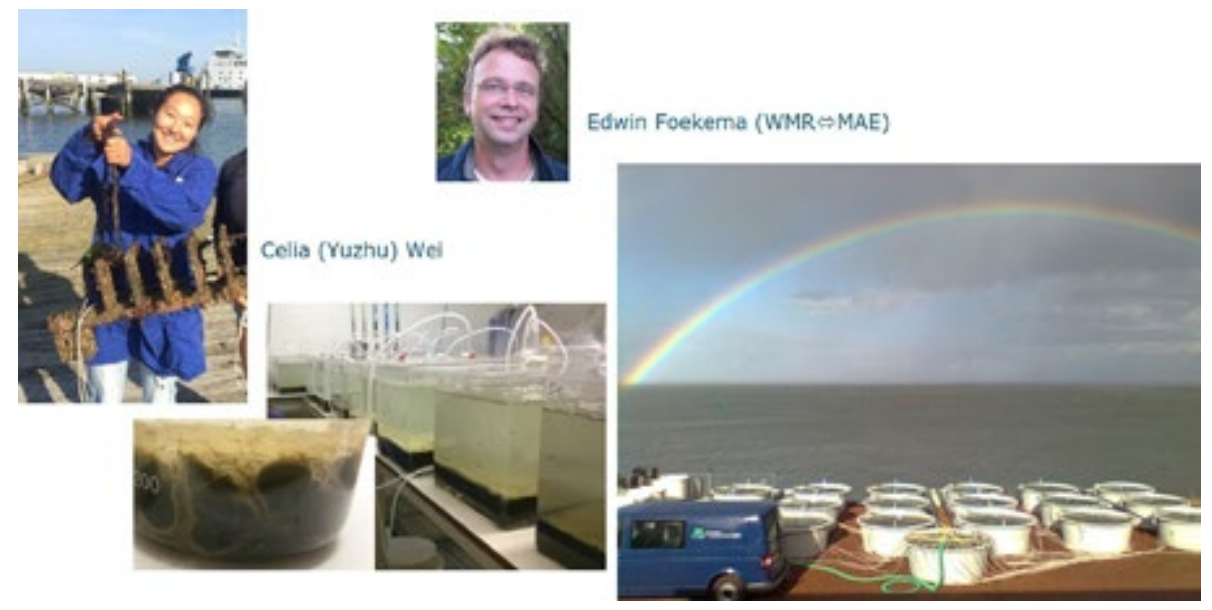

Figure 16: Multi species tests in marine micro- and mesocosms.

Edwin Foekema, part time scientist in our group and at the research institute Wageningen Marine Research, is very experienced in model ecosystem work with multiple species (figure 16). Many students participate in this research. 
One of the PhD students making use of the model ecosystems, in addition to laboratory work, is Celia Wei. She works within the project called GasDrive, a collaboration with the technical universities of Delft and Twente. In this project a novel engine propulsion system is being developed that should emit hardly any toxic compounds, only $\mathrm{CO}_{2}$. This exhaust gas then will be released along the ship's hull where it is retained by special nano-structures in order to strongly reduce the drag of the ship. The questions Celia aims to answer are: what is the impact of releasing $\mathrm{CO}_{2}$ directly in the sea water, depending on the local environment, and, what is the anti-fouling activity of $\mathrm{CO}_{2}$. It appears that anti-fouling paint will not be needed when this system would be applied.

PhD student Park Bao, who just came back from China last night, studies the effects of the quite high levels of a diverse array of persistent toxic compounds in the sediments of the Yangtze river delta. His focus is on the consequences for the local benthic ecosystem as well as for the seafood quality. Park is involved in ecological field monitoring, and also develops and applies biomarkers and bioassays to quantify the toxic potencies, including a novel 'lab on a chip' assay with nematodes.

Last month we were happy to learn that the C-IMAGE consortium (that includes our team) was granted a third period of funding. The C-IMAGE consortium is studying the impact of the Deep Water Horizon blow out and of the subsequent application of oil spill dispersant on the Gulf of Mexico marine ecosystem. A major remaining area of impact to study is on the benthic ecosystem, which is now covered with oiled sea snow and other formerly suspended material. We demonstrated that dispersant application during phytoplankton bloom stimulates the production of extracellular polymeric substances which forms marine snow with dispersed oil and clay minerals, sinks to the sea floor and suffocates the benthic life ${ }^{20}$. Historic sediment core samples from an 38 years old blow out in the Gulf of Mexico, the IXTOC, reveal that this has occurred before and that bioturbation never returned until decades later the sediment was covered by a fresh layer of sediment.

Although hardly anybody goes there, also the deep sea benthic system is very important for a healthy marine ecosystem, also in more shallow areas. Many species migrate up and down or live parts of their life in deeper waters and feed there.

A naturally produced, quite nasty compound is tetradotoxin, or TTX. This is the neurotoxic compound that also makes the pufferfish deadly toxic. TTX will survive cooking, so levels in food should be managed. Mostly TTX occurs in warmer waters,

20 For more info: www.wur.nl/en/project/C-IMAGE-Deepwater-Horizon-oil-spill.htm 
like the Mediterranean Sea. Since 2015, however, it was found in the Dutch Eastern Scheldt as well (figure 17) in June-July, when the water temperatures rise above $18{ }^{\circ} \mathrm{C}$. Unfortunately TTX also accumulates in shell fish, so during outbreaks the mussels cannot be sold. Marnix Poelman from WMR is highly involved in monitoring the TTX in the field. Reindert Nijland, a molecular marine microbiologist from MAE, is trying to unveil the source of TTX and the trigger for its production. None of the organisms known to contain TTX producing bacteria have yet been observed in the Eastern Scheldt.

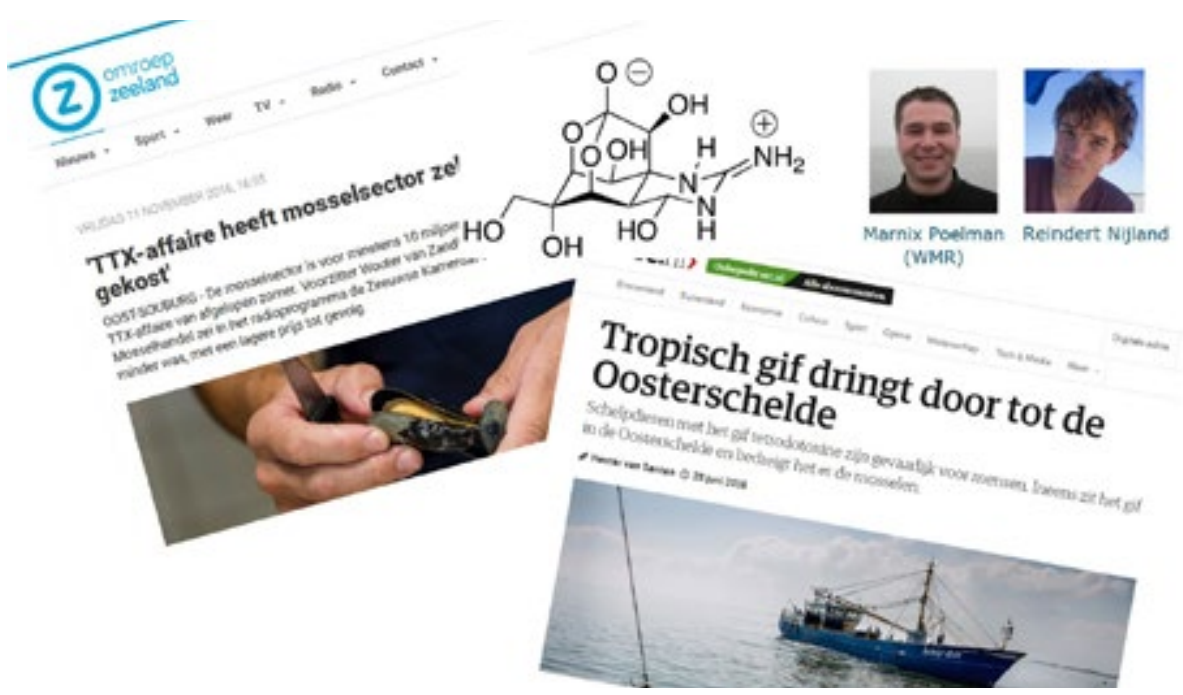

Figure 17: Revealing the trigger and producer of Tetradotoxin (TTX) in the Dutch Eastern Scheldt.

\section{4) Eco-inspired restoration and kick-starting of marine habitats}

A field where MAE has a lot to contribute is that of eco-inspired design. Given the tremendous importance of reefs as habitat for marine species it is important to think about this in an as early as possible stage of planning of any activity.

Via ecology-inclusive planning and building (or not decommissioning ${ }^{21}$ ) of offshore structures, we can create new habitats and fill the spatial gaps between marine protected areas to enable a functional ecological network. The effectiveness of the designs should be monitored to steer further improvement. Within MAE we have several projects on reef restauration and creation, including $2 \mathrm{PhD}$ projects.

21 Fowler et al., 2018. Environmental benefits of leaving offshore infrastructure in the ocean. Front Ecol Environ; doi: 10.1002/fee.1827 
Within the REEFolution Kenya project, PhD student Ewout Knoester studies how facilitators of healthy reefs can be facilitated. In the Kenyan marine park around Kisite Island, parts of the reef had been blown away by dynamite fishing. This practise is now effectively managed, but without hard substrate it is very hard for a coral reef to come back. We want to kick-start reef recovery and grow new corals from broken parts that barely survive in the sand. This is currently done all over the world and tedious cleaning of the culturing structures is required to prevent the periphyton from overgrowing the corals. Of course people never need to do this in natural reefs, so we wondered whether these housekeepers could help us as well.
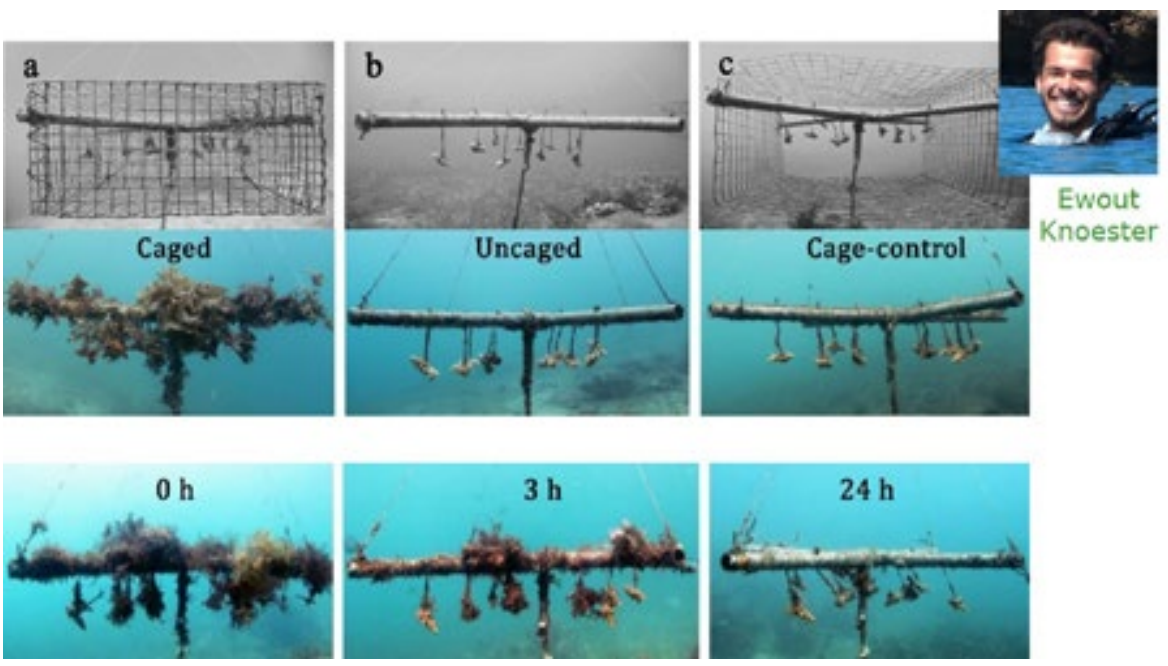

Figure 18: Fish exclusion experiment (100 days) in the Wasini Channel by Ewout Knoester. Without access for fish (a) the coral fragments got overgrown by periphyton and finally will die. This was not the case with the (partially) uncaged fragments $(b, c)$. Within hours after uncaging the corals were cleaned by fish $(d)$.

The trees that could not be reached by herbivores were fully overgrown, the open trees nicely cleaned. Some fish had been nibbling from some coral pieces, but this was a small loss compared to the gain. At the end of the experiment all cages were opened and placed next to the healthy reef. The result was spectacular (figure 18). Already after 3 hours the periphyton had been removed, and after 24 hours the trees were completely clean. Of course the formerly covered coral pieces still were very small as they had no chance to grow under all the algae.

The greater REEFolution project also involves people of the local community in the reef restauration and building. Children are educated on the importance of a healthy reef. Very recently the local beach management agreed to establish a no-take zone 
where reef restauration and recovery can be optimised. Around this area habitat enhancement will focus at attracting for them interesting seafood species that will be harvested in a habitat-friendly way.

$\mathrm{PhD}$ student Alwin Hylkema is comparing the effectiveness of different structures and material as reef building blocks. The 3-D shapes determine the housing capacity for herbivores that need to prevent overgrowing of the reef by fouling organisms and macro algae. An important housekeeper is Diadema antillarum. Where this long spined sea urchin is not present in Caribbean coral reefs, its state seriously deteriorates. Alwins preliminary results show that layered cakes provide much more habitat for fish than the dome-shaped reef balls (figure 19) 22 .

Alwin Hylkema (VHL@MAE)
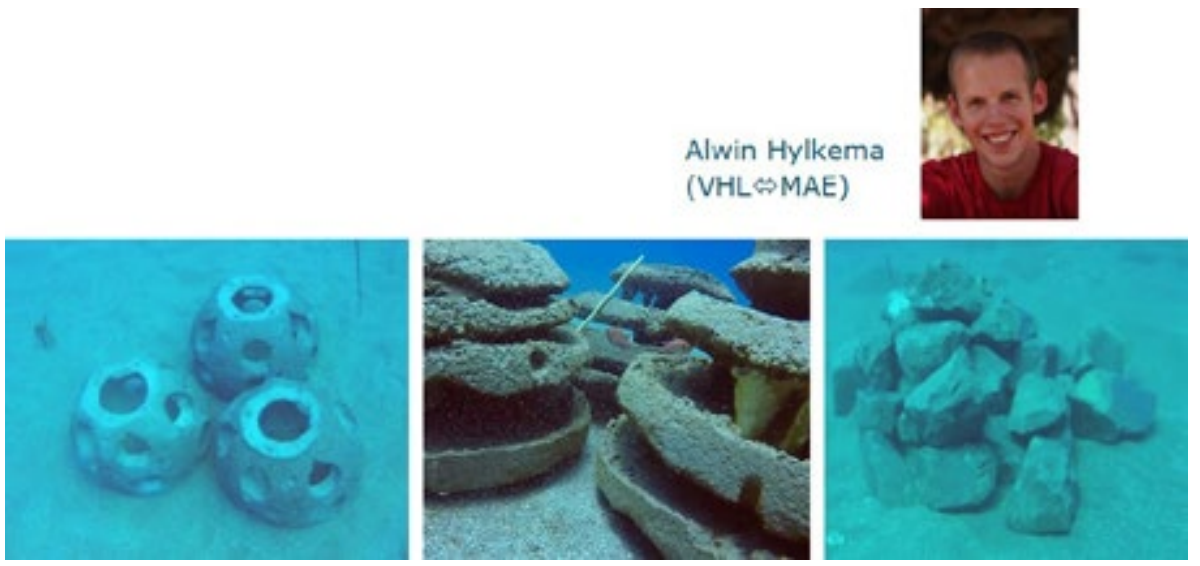

Figure 19: Habitat provision via 'classical' dome-shaped reef balls, layered cakes and natural rocks. Layered cakes provide optimal housing. PhD project Alwin Hylkema22

Unfortunately hurricane Irma has moved the structures around quite a bit. Still fish were hiding in the layered cake reef balls, and they even stayed in when the cake halves were put on top of each other again. We are considering changing the design to make the structures less prone to hurricanes.

\section{Scientific basis for marine conservation management}

As for the other themes I will only briefly show some of the $\mathrm{PhD}$ projects, although we are involved in more projects that provide the scientific basis for marine conservation management. Let me start with some good news: on 28/10/17 the Bonn convention decided it is very important to also protect far migrating marine animal

22 www.youtube.com/watch?v=pcO3IotxQSM; www.facebook.com/AROSSTAVHL/ 
species. The problem, however, is that we hardly know how these animals use their environment.

PhD student Sahri Achmad (figure 20) studies the habitat-use by cetaceans in Wakatobi marine park, Indonesia. Are they just migrating or resident? Do they feed there or give birth to pups. This information is needed to optimize the cetacean conservation by more dedicated spatial planning and marine park management. Sahri will use already existing visual monitoring data but also wants to apply tags to register the horizontal and vertical behaviour of individual animals over specific time intervals.

The project of PhD student Inger van den Bosch (figure 20) is somewhat related to that of Sahri, but she studies the habitat use of harbour porpoise in the North Sea. She cannot apply tags because the animals are too small. In addition to also using already available monitoring data, Inger wants to assess the body condition of the animals by filming them from above using a drone. By now Inger is a certified drone pilot, and next year we hope to know how effective this non-invasive approach is for harbour porpoise.
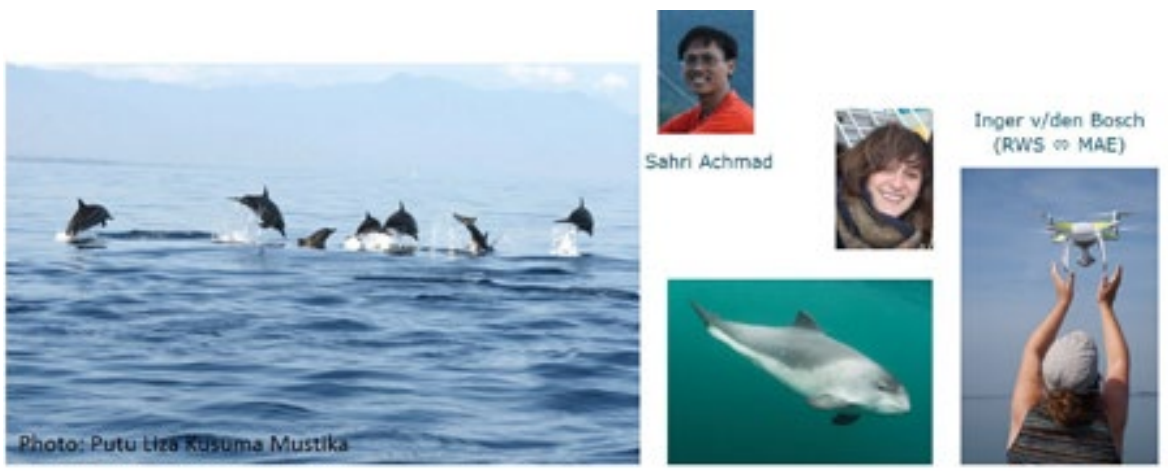

Figure 20: Habitat use by cetaceans in Indonesia (Spinner dolphins, Stenella longirostris) and the Netherlands (harbour porpoise, Phocoena phocoena).

The most recent project on charismatic species is that of MSc student Lukas Mueller. Lukas has been tagging hammer head sharks, as these animals migrate over long distances but yet it is not known where they exactly go, at what depth and how they use their habitat. As with the tags Sahri wants to apply, the hammer head tags will record the parameters needed to create a 3D image of their habitat use.

In addition to the natural sciences part, Lukas is very active with virtual reality technology. Virtual reality enables people to experience distant places that otherwise 
will not be accessible for them. Making the invisible visible can help involve people in the underwater world. During the reception there will be an opportunity to experience a light version of virtual reality. Lukas has prepared a short try out demo for those who are interested.

\section{Scientific support for sustainable use of marine resources}

From 1950 to 1990, the worldwide catch of fish has increased by about 400\%, made possible by the rapid increase in engine power and industrialisation of fisheries. I already showed that with such a drastic increase, the numbers of several species of fish decline substantially. For a more sustainable use and management of marine resources and systems, it is crucial to take the context of the changing environment and other anthropogenic activities into account. This should include the connectivity between the different habitats needed by animals in different stages of their life cycle. It may be that the health of mangrove nurseries are crucial for the presence of adult fish caught hundreds of kilometres away.

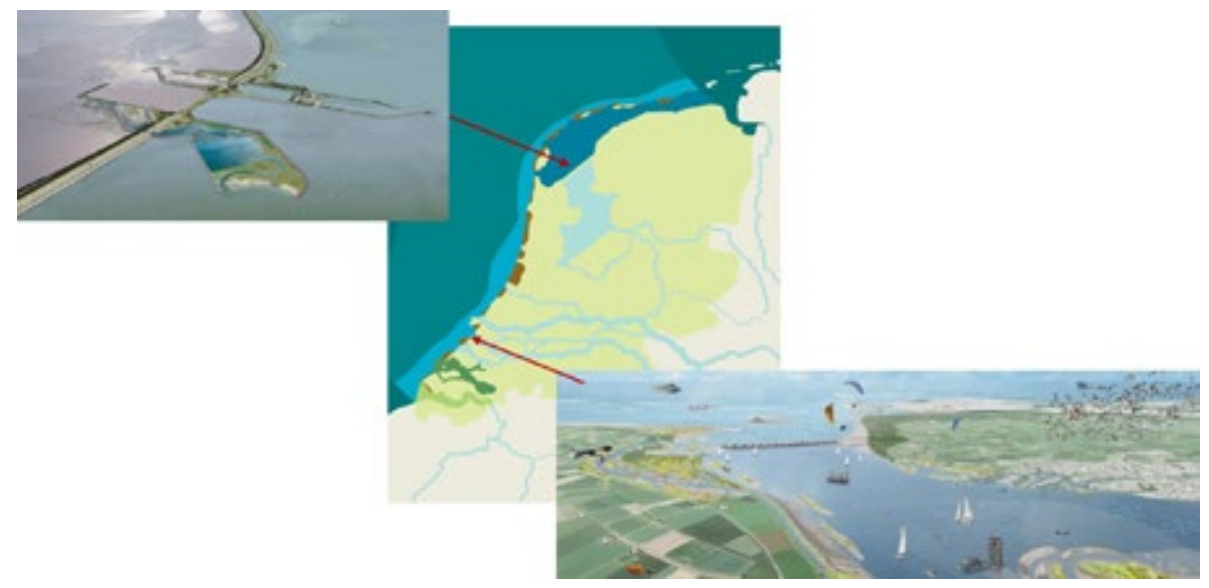

Figure 21: of fish migration river in the Afsluitdijk ${ }^{23}$ and the Haringvliet ${ }^{24}$. The last will be effective from September 2018 onwards.

Many fish species need to migrate to brackish and even fresh water in order to fulfil their life cycle, and currently this is a problem in many places in the world, including the Netherlands. That is why I am so thrilled about the upcoming experiments of

23 Fish migration river: www.theafsluitdijk.com/projecten/fish-migration-river/

Haringvliet: Griffioen et al., 2017. Prognose visstand in en rond het Haringvliet na invoering van het Kierbesluit in 2018 (doi.org/10.18174/425507, in Dutch). 
creating openings in two large barriers for fish migration, in the Haringvliet and the Afsluitdijk (figure 21). This should enable many catadromous and anadromous species like eel and salmon, to fulfil their lifecycle again. But also less well known species will profit. Of course it is very important not to immediately place long gill nets or fish pods in the neighbourhood of these rare migration routes!

As I indicated, reefs are essential habitats for many species of marine animals, either for early life stages, or for adult organisms themselves. It is important to facilitate both ecological key stone species as well as harvestable species, and to better understand the full life cycle requirement of these targeted species. This will enable dedicated spatial management within the complex context of anthropogenic pressures and changing conditions. Too often the main focus is on the survival and adaptation of the adult life stage, but all life stages have to be able to thrive for a well-managed population (figure 22).

Based on the understanding of the traits of targeted species, the harvestable biomass of several reef-dependent species can be enhanced, for example by smartly designed habitat around the turbines in windfarms. We are investigating in a current MSc project, co-supervised by Jan Jaap Poos of WMR, how productivity of European lobster, edible crab, cod and thornback ray will increase via eco-inspired enrichment of the scour protection. In addition, we study options and spatial planning for ecosystem friendly, habitat saving fishing methods.

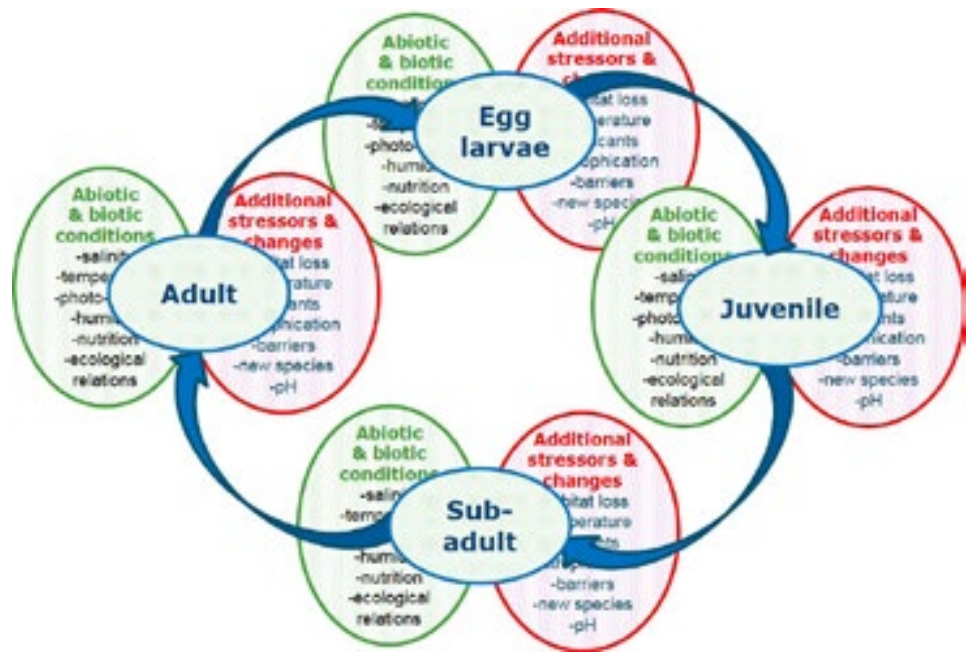

Figure 22: For a resilient population each life stage has to thrive in its suitable habitat under the given abiotic and biotic conditions and additional stressors and environmental changes. 
The seafood harvest per ha, both in terms of kilo's as well as euro's could be a magnitude of what could be achieved via the habitat destructive bottom trawling methods. It would be great to test such a sea ranching approach for a at least 10 years and monitor the productivity and ecological impact to be able to optimise and modify the approach. This should all be done in collaboration with all stakeholders involved in the developments at sea, especially knowledgeable fishermen interested in innovations. Comparable to the terrestrial developments (figure 23), we need to move from a traditional hunter/gatherer approach to a more sustainable, productive and animal friendly system to harvest food from sea as well.

It would also be great if we could involve society in monitoring the success of such activities. Following the example of 'visspotter.nl', a form of citizen science, nondivers can follow the developments under water and contribute to the monitoring effort as this is applied for studying the success of fish passages in rivers. This 'visspotter' approach could also be applied for participative monitoring of migrating animals through the upcoming fish passages in the Haringvliet and Afsluitdijk.

With meta-barcoding in projects together with WMR and the NIOZ, MAE studies what species settle on offshore structures in the North Sea, even before they are visible. In addition we will apply eDNA monitoring to be able to determine what mobile animals make use of certain structures. In water samples the DNA from cells that originate from e.g. skin of sharks and rays and other fish can be analysed to reveal their presence.

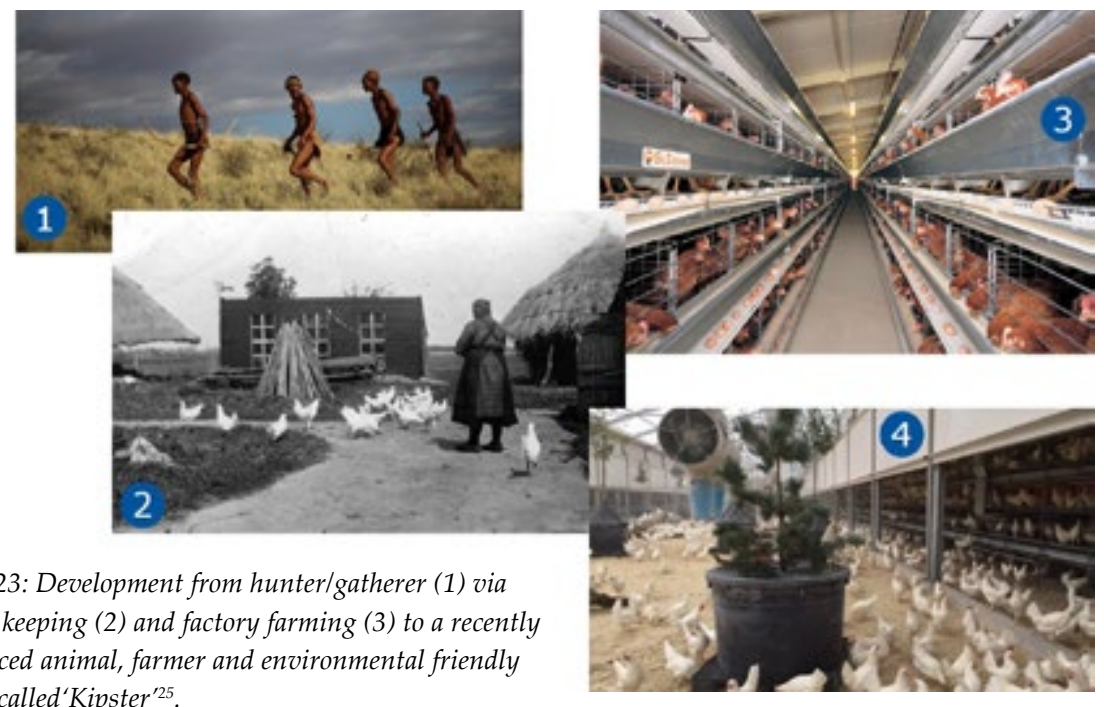

Figure 23: Development from hunter/gatherer (1) via chicken keeping (2) and factory farming (3) to a recently introduced animal, farmer and environmental friendly system called'Kipster'25.

25 www.kipster.farm/ 
It is surprising that mostly carnivorous fish species are being cultured, such as salmon and tuna, species that in nature also migrate over long distances. Farm animals are mostly herbivores such as cows, chicken and sheep and omnivores such as pigs. The higher the trophic level of a species, the lower the resource efficiency. Every trophic level step requires about 10 times more resources per kilogram of product. Therefore culturing marine herbivores, omnivores, and detritivores could greatly improve resource use efficiency.

In addition I would expect that species with a short natural home range will be less stressed when caged than migrating species. So an eco-inspired selection of candidate species for aquaculture could be a step towards improving animal welfare, resource efficiency and a reduced environmental footprint. A short search out of curiosity, yielded this potential candidate fish (figure 24). The herbivorous Blackfish $^{26}$, also called black bream, lives in estuaries, mangroves, rocky reefs and inshore coastal waters in Australia and New Zeeland. They flourish in seagrass areas and are often seen in large shoals.

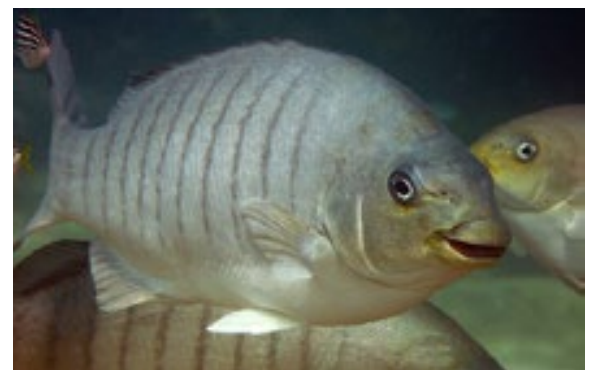

Figure 24: Blackfish, Luderick or Black bream (Girella tricuspidata), an example of a herbivorous, social, reef fish native to New Zealand \& Australia ${ }^{26}$ that may be a suitable marine aquaculture fish.

This summer, during a long and great day on a mussel farmers ship, I learned a lot about the struggles with crabs and starfish. After 'seeding' about $40 \%$ of the very young mussels in the Eastern Scheldt is eaten by crabs. For the surviving mussels especially star fish are serious predators. Twice a year a large mop is used to remove massive amounts of starfish from the mussel beds. There are, however, several natural enemies of especially younger starfish and crabs, such as sharks, rays, sea bass, cod and probably eel. Like agriculture is gradually discovering the benefits of a more eco-inspired approach towards crop protection, I expect that mussel aquaculture can profit from natural allies in order to greatly reduce the predation mortality. To facilitate the facilitators, a more ecosystem based management is needed to balance the interests of the various stakeholders. It is no use attracting the desired species without preventing others from (over)fishing them.

26 https://australianmuseum.net.au/luderick-girella-tricuspidata 
An overarching project team is needed to successfully manage all ecosystem services of an important and complex system such as the Eastern Scheldt. It is time for a Rich Eastern Scheldt programme, inspired by the success of the Rich Wadden Sea programme (PRW). Until we have a minister for North Sea affairs, an overarching Rich and Viable North Sea programme would be a good start to enable ecosystem based management of the developments in the North Sea.

As outlined in this address, we urgently need to assess the vulnerability of the marine ecosystems for global and local anthropogenic drivers of change and take measures to protect and enhance ecosystem functioning, productivity and resilience.

Although in the recent government agreement the North Sea was not mentioned at all, I sincerely hope this does not imply a lack of attention for the interests, changes, challenges, competing claims, and international issues concerning this large part of the Netherlands. Although not as visible as the Wadden Sea, much more is happening and going to happen in the North Sea, including 'Blue growth'.

\section{Education}

Clearly also more information and education is needed to increase general ocean literacy. MAE is teaching Dutch and international students the basics of marine animal ecology, but also the important contributions it can make to the challenges we face as I outlined before.

Since the start of MAE 2 years ago, we have had, and still have, the pleasure to coach over 100 MSc and BSc students with their thesis and internship. Those students really contribute to the dynamics and successes of the growing MAE. We also teach several courses at MSc and BSc level. This includes the interdisciplinary course Environmental Quality and Governance that makes students realise that natural sciences can contribute to understanding the basis of changes, but that good knowledge alone is not enough to make things happen. Changes happen within the broader dynamical context of the golden tetrahedron of society, science, industry and government.

\section{Thank you!}

Of course there are many, many people and groups to thank.

In the period of my 1st inaugural speech, the article: Better happy than professor (figure 25) was published in the Resource. In my opinion, this is a nonsense reasoning. As long as you have the privilege to work in a great team with whom you can share ideas and tasks and make plans. 


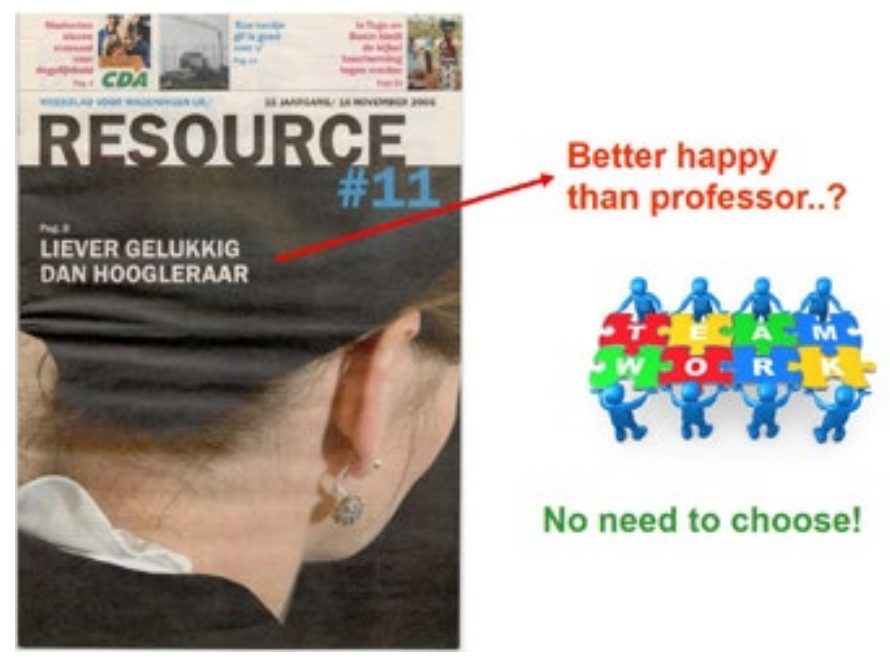

Figure 25: Resource article 2006: 'Liever gelukkig dan hoogleraar' ('Better happy than professor') (?!)

Already soon after the start of MAE my two experienced colleagues Lisa Becking and Ronald Osinga joined. Because of our already existing networks, we could start doing research, also with students, months before we had housing and a lab. Our collaborations stimulate creativity and resource efficiency, and we do not plan to change that approach. Soon also PhD students joined MAE and contributed greatly with their talents, experiences, passion and knowledge. I am sorry that I could not show the work of all your projects, time is limited, but it certainly does not imply your work is less relevant!

MAE is clearly a diverse, dynamic and resilient group. I foresee further sustainable growth in the near future, in close interaction with an ever changing environment. We are very happy with the opportunities we have to collaborate with our many research partners, within and outside Wageningen and the Netherlands. Without these great collaborations MAE could not even try to achieve its ambition.

Specifically I would like to thank the people of Wageningen University and Research that supported me, believed in me and taught me the skills that made me who I am. The former professors, that I worked with, Jan Koeman, Bram Brouwer, Ivonne Rietjens and Huub Rijnaarts, people with totally different personal qualities and talents. Martin Scholten, Raoul Bino, Martin Kropff and others who also supported me during steps I took in my career. 
Also a big thank you to my former and current colleagues of Toxicology, Imares and Environmental technology that made my working life worthwhile and happy. And to the people of the CTGB, the North Sea foundation, the REEFolution foundation and the Duik de Noordzee Schoon team, that gave me the opportunity to think about scientific issues in totally different contexts.

\section{In Dutch I would like to thank my family and friends.}

Natuurlijk is een mens niets zonder een geweldige familie, buren en andere vrienden. Ik prijs mij gelukkig met jullie gezelligheid, humor en support.

Allereerst dank ik mijn vrienden van de Heiduikers en de Nordic Sports vereniging Troll. Het is niet te overschatten hoe belangrijk het is om naast je werk druk te kunnen zijn met heel andere dingen. Bijvoorbeeld tijdens duiktrips in het buitenland of binnen Nederland. Jazeker, je kunt ook erg mooi duiken in Nederland!

Op een andere manier adembenemend zijn de Troll trappen trainingen met Sjaak, Edward en Bert. Voortvloeiend uit deze trainingen ben ik afgelopen jaar dingen gaan proberen waarvan ik nooit had gedacht dat ik ze kon, zoals de halve Renkumse cross triatlon en een $20 \mathrm{~km}$ lange stuwwal trail. Allemaal supergoed om je hoofd leeg te maken.

In het bijzonder wil ik mijn ouders bedanken. Jullie vormden de basis van wie ik nu ben. Ik heb van jullie geleerd doelen te stellen en daar naar toe te werken, niet te snel op te geven maar ook tevreden of trots te zijn als er iets lastigs gelukt is. Jullie hebben mij toen ik jong was, de ruimte gegeven maar ook gesteund, gekke biologenfratsen geaccepteerd en belangstelling getoond. Geweldig dat jullie er gewoon weer bij zijn. Heel erg bedankt voor alles en dat jullie nog maar lang trots op mij mogen blijven!

Mijn laatste woorden van dank gaan uit naar mijn 2 mannen, die allebei echt niet in het centrum van de belangstelling willen staan: Dick, fijn dat je er bent met je kritische blik en relativerende opmerkingen, dat je er bent als het nodig is en dat ik altijd op je kan rekenen. Loek, je weet niet half hoe geweldig het is om een zoon zoals jij te hebben. Je bent nu sinds kort voor je studie op kamers, maar in het weekend is er gelukkig nog genoeg tijd om met elkaar dingen te doen en bij te praten. Ik ben erg trots op je, en verwacht dat nog erg lang te blijven!

Ik heb gezegd! 





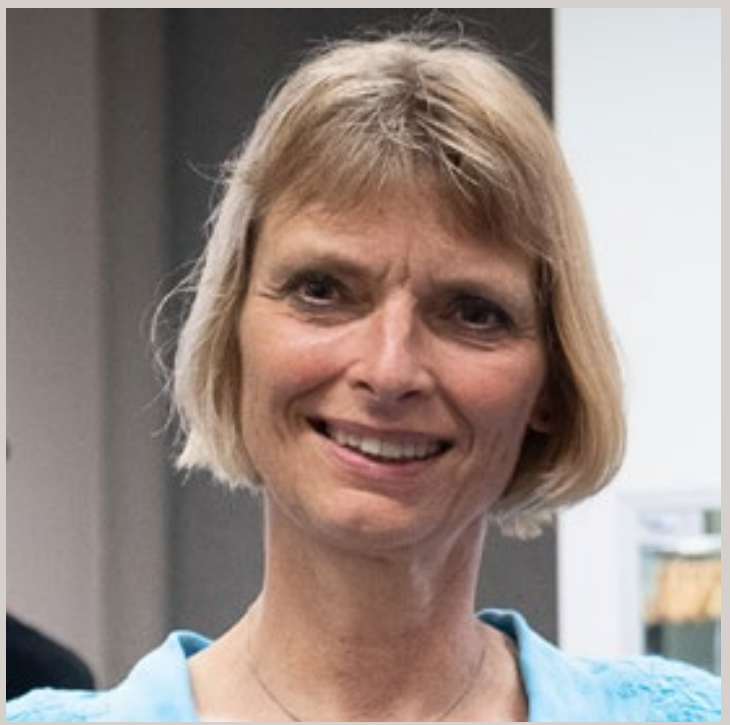

Prof.dr A.J. Murk

'Since centuries people are intensively using the marine environment. The health, biodiversity and resilience of the marine ecosystems that provide the basis for these uses are increasingly under pressure. Only with a transition towards nature inclusive design, spatial planning and operation can the ambition of 'Blue Growth' be realised while habitat and species biodiversity recover instead of further deteriorating. Nature follows opportunities, therefore we greatly influence what ecosystems develop. By providing a smart diversity of high quality habitats, safe connectivity between them and complete food webs including apex predators, we enable the biodiverse, productive and vital marine ecosystems that our children, and theirs, deserve.' 